\title{
Job stressors and other risk factors related to the risk of hypertension among selected employees in Jakarta
}

\author{
Feni Krisnawati ${ }^{*}$, Bastaman Basuki ${ }^{*}$, Ginova Nainggolan ${ }^{f}$
}

\begin{abstract}
Abstrak
Hipertensi dapat terjadi pada semua orang termasuk para karyawan. Salah satu faktor risiko hipertensi antara lain adalah faktor stresor di lingkungan kerja. Oleh karena itu perlu diidentifikasi faktor stresor kerja dan faktor lainnya yang berpengaruh terhadap risiko hipertensi. Desain penelitian ialah nested case-control. Kasus adalah karyawan yang menderita hipertensi (berdasrkan lapotan ke enam Joint National Committee on high blood pressure, Amerika Serikat 2003), atau sedang makan obat antihipertensi. Satu kasus dipadankan dengan dua orang kontrol menurut tahun kasus didiagnosis hipertensi dan menurut jenis kelamin. Kontrol dipilih di antara karyawan yang tidak pernah menderita hipertensi. Semua faktor risiko pada kasus dan kontrol dihitung sampai saat kasus didiagnosis hipertensi. Penelitian dilaksanakan di antara karyawan kantor pusat PT A Jakarta bulan Mei 2004 dengan jumlah karyawan 255 orang. Diperoleh 70 kasus hipertensi dan 140 kontrol. Subjek berumur 25 sampai 65 tahun. Risiko hipertensi berkaitan dengan stresor beban kualitas berlebih, stresor beban kuantitas berlebih, pengembangan karir, umur tua (55-65 tahun), obesitas, merokok, dan adanya riwayat hipertensi di antara keluarga. Sedangkan faktor ketaksaan peran, konflik peran, dan tanggung jawab tidak terbukti mempertinggi risiko hipertensi. Jika dibandingkan dengan stresor beban kualitas ringan, stresor beban kualitas sedang-tinggi mempertinggi risiko hipertensi 7 kali lipat [rasio odds (OR) suaian = 7,47; 95\% interval kepercayaan $($ CI $)=1,40-39,76$ ]. Selanjutnya jika dibandingkan dengan stresor beban kuantitas ringan, stresor beban kuantitas yang sedang - tinggi mempertinggi risiko hipertensi 4 kali lipat (OR suaian $=4,10 ; 95 \%$ CI =1,06-15,90). Disimpulkan bahwa stresor beban kualitas berlebih, stresor kuantitas berlebih dan stresor pengembangan karir (moderat) mempertinggi risiko hipertensi, oleh karena itu stresor tersebut perlu dicegah. (Med J Indones 2006; 15:177-84)
\end{abstract}

\begin{abstract}
Almost everyone, including employees, may develop hypertension. Several risk factors, including stresses in the work environment, are related to hypertension. The aim of this study is to identify these work-related risk factors in hypertension. A nested case-control study was conducted among office employees in Jakarta during May 2004. Employees with stage 1 or stage 2 hypertension (based on the United States of America Joint National Committee on high blood pressure 2003), or those taking antihypertensive drugs were designated as cases. As controls were employees with no history of hypertension. One case was randomly matched by gender with two controls. All risk factors for cases and controls were counted as of the reference date of diagnosis for cases. There were 70 cases and 140 controls aged 25 to 65 years. Hypertension was found to be related to the qualitative and quantitative increase in the workload, career development, age, obesity, current and past smoking habits, and a family history of hypertension. However, it was noted that role of ambiguity, role of conflict, and personal responsibility did not increase the risk of hypertension. Compared to those with low qualitative job stressor, those who had moderate or high qualitative job stressor had a seven-fold risk to be hypertensive [adjusted odds ratio $\left(\mathrm{OR}_{\mathrm{a}}\right)=7.47 ; 95 \%$ confidence interval $\left.(\mathrm{CI})=1.40-39.76\right]$. In addition, relative to those who had low quantitative job stressor, those with moderate or high stressors were four times at risk to be hypertensive $\left(\mathrm{OR}_{\mathrm{a}}=4.10 ; 95 \% \mathrm{CI}=1.06-15.90\right)$. In conclusion moderate or high qualitative and quantitative job stressors as well as career development increased risk hypertension. Therefore these stressors need to be prevented. (Med J Indones 2006; 15:177-84)
\end{abstract}

Keywords: hypertension, qualitative job stressor, quantitative job stressor, career development

Indonesia is undergoing a transition, from infectious or communicable diseases to degenerative diseases or

\footnotetext{
* Department of Community Medicine, Faculty of Medicine, University of Indonesia, Jakarta, Indonesia

${ }^{f}$ Department of Internal Medicine, Faculty of Medicine, University of Indonesia/Dr. Cipto Mangunkusumo Hospital, Jakarta, Indonesia
}

noncommunicable diseases such as hypertension. ${ }^{1}$ Special attention should therefore be given to this disease, since hypertension will need life-long treatment and can be fatal. ${ }^{2,3}$ Epidemiological surveys have shown that the prevalence of hypertension Indonesia range from $0.6 \%$ in the Baliem Valley of Irian Jaya to $20.9 \%$ in Bogor. ${ }^{1,3}$ 
Hypertension can be the result of multiple factors, such as gender (men and postmenopausal women); old age; lifestyle: low physical activity/exercise, stress, obesity, smoking, unhealthy diet; diseases: dislipidemia, diabetes mellitus; genetic factors: family history of cardiovascular disease; discontinuation of hypertensive treatment; work-related stress; and other factors. ${ }^{1,3,4}$

The prolonged economic crisis in Indonesia has made an impact on current working conditions. Efforts to make various industries more efficient have resulted in many lay-offs or downsizing to streamline the work force. These efforts have increased individual work loads and cause managerial problems. In turn, it may influence the psychological conditions of the employees, causing work-related stress. ${ }^{5}$

A survey in New York found that cases of hypertension was 2.7 times higher compared to normal in employees with deep work-related stress. ${ }^{6}$ It is therefore important to identify work-related stressors that may influence hypertension in the working environment of Indonesia, as an effort in controlling hypertension. This paper will show the influence of work-related stressors and other risk factors on the risk of hypertension in employees of a Jakarta head office.

\section{METHODS}

The design of the study was a nested case-control study. ${ }^{7}$ It was conducted in a office in Jakarta during the month of May 2004, with active employees working at least for 6 months (normal adaptation period) and willing to participate in this study after signing an informed consent form. Subjects with a history of coronary heart disease, stroke, renal diseases or a history of hypertension prior to employment were excluded.

Cases were employees with stage 1 and 2 hypertension based on the seventh report of the United Sates of America Joint National Committee on high blood pressure $2003(\mathrm{JNV} 7)^{8}$ or taking antihypertensive medication. Controls were employees without hypertension until the end of data collection. One case was matched for 2 controls by the year the case was diagnosed as hypertension and by gender. All risk factor for cases and controls were counted as of the reference date of cases diagnosed.

Identification of cases and controls was begun by surveying the blood pressure of 208 subjects of the total office employee. The data collected were demographic characteristics (age, marital status, education), employment (level of employment, type of employment, length of employment, additional position, and work-related stressor), and lifestyle.

Blood pressure measurements were done according to JNC $7 .^{8}$ All measurements were taken by the first author between 09.00 to 13.00. The first blood pressure measurement was taken after resting at least for 5 minutes. The second measurement was taken 2 minutes (or more) after the first measurement. Both values were averaged. If the difference between the two measurements was more than $5 \mathrm{mmHg}$, then a third measurement was taken, and the values averaged. ${ }^{8}$

Body weight was measured in kilograms $(\mathrm{kg})$ using a calibrated scale (SECA, Germany). The subjects were measured in their everyday work clothes but without shoes. The measurement was needed to confirm the weight obtained through anamnesis when diagnosis of hypertension was established.

Height was measured in centimeters $(\mathrm{cm})$ using a calibrated measuring instrument (SECA, Germany). At the time of measurement, the subject was without shoes. The data was used to confirm height in the year diagnosis of hypertension was established, since height should remain relatively unchanged.

Interviews with questionnaires comprising of a questionnaire for obtaining general data on: name, age, sex, marital status, education, and record of employment; and a questionnaire on risk factors of hypertension: physical activity (household, work, and exercise activities), coffee, smoking, history of diseases of the respondent as well as the family, use of antihypertensive drugs, and hormonal contraceptive drugs (for female respondents).

The stress diagnostic questionnaires comprised of 30 questions on 6 types of work-related stressors: (1); (2); (3); (4); (5); and (6) according to Ministry of Health Guidance on Action on Stress at Work. ${ }^{9}$ The respondents filled in the answers to each question by rating from $1-7$ conditions that give rise to stress. A rating of 1 means conditions that will never give rise to stress; 2 means conditions that hardly ever give rise to stress; 3 means conditions that rarely give rise to stress; 4 means conditions that sometimes give rise to stress; 5 means conditions that frequently give rise to stress; 6 means conditions that very frequently give rise to stress; and 7 means conditions that always give rise to stress. 
Interpretation for each stressor was grouped according to the relevant 30 numbers of the stress diagnostic questionnaires. (1) Role ambiguity score: sum for the answers to question numbers $1+7+13+19+25$; (2) Role conflict score: sum for the answers to question numbers 2+8+14+20+26; (3) Quantity workload score sum for the answers to question numbers: $3+9+15+21+27$; (4) Qualitity workload score: sum for the answers to question numbers $4+10+16+22+28$; (5) Carrier development score: sum for the answers to question numbers $5+11+17+23+29$; (6) Personal responsibilty score: sum for the answers to question numbers $6+12+18+24+30$. Total job stress score was derived by the sum of each stressor, and furthermore was divided into: low stress $=$ total score was less than 10 ; moderate stress $=$ total score $10-24$; highstress $=$ total score more than $24 .{ }^{9}$

Secondary data were obtained from medical records and data from the yearly medical check-up of December 2003 - January 2004 in the outpatient clinic. The data were used to reconfirm data obtained during the study.

Statistical analyses were done using STATA 6.0 software. ${ }^{10}$ Several risk factors were examined for potential confounders and/or effect modifiers. Unconditional logistic regression analysis was used in order to determine the confounding effects and to determine the risk factors for hypertension. A risk factor was considered to be a potential confounder if in the univariate test the $P$-value $<0.25$ and would be considered as a candidate for the multivariate model along with all known risk factors for current antihypertensive medication. ${ }^{11}$ Confounders were estimated by maximum likelihood. Ninety-five percent confidence intervals were based on the standard error of coefficient estimates. Odds ratios (OR) were estimated by maximum likelihood. ${ }^{12}$

Approval for this study was granted by Board of Examiners of the Department of Community Medicine, Faculty of Medicine University of Indonesia in Jakarta.

\section{RESULTS}

The office, where this study took place, has implemented a stress management program for all employees. The program was carried out by the office medical team.
Out of 255 potential subjects, 223 met the inclusion criteria and agreed to join the study. Eleven subjects $(4.3 \%)$ refused to participate and $21(8.2 \%)$ gave no reply. Out of 223 respondents, 6 potential controls did not complete the questionnaire on work-related stress and could not be included in the study. Among the 217 subjects, 70 were identified as hypertensive cases and 147 were normotensive. Since only 140 controls were needed, 7 were randomly excluded from this study.

The number of new cases of hypertension fluctuated each year, the highest was in 2001, followed by 2003. All subjects were found to have light work loads. A majority of the hypertensive subjects $(77.1 \%)$ were still under antihypertensive treatment.

The results crude odds ratio test in Table 1 , showed that marital status was not correlated with hypertension. Compared to subjects with a junior high school education, those with a higher education tend to have a higher risk of hypertension. When compared to low occupational level, subjects with a higher occupational level tend to have a higher risk of hypertension. The supervisors and advisors tend to have a higher risk of hypertension than the general staff. The same tendency was also found in subjects who have been working for 11 years compared to those working for 10 years or less.

Table 2 showed that those with moderate house hold activities, daily coffee drinking habits, and higher role ambiguity, higher role conflict, or higher personal responsibility scores were at an increased risk of being hypertensive.

The final model, as shown on Table 3, revealed seven risk factors were related to hypertension, namely: age, BMI, exercise and smoking habits, family history of hypertension, quantity as well quality of work load, and career development. Increasing age and higher BMI tend to increase the risk to be hypertensive. Those with moderate exercise tend to have a lower risk of being hypertensive compared to those with light exercise.

Furthermore, those with a family history of hypertension, higher quality and quantity working load as well as career development scores had an increased risk of hypertension. 
Table 1. Some demographic characteristics, job and risk of hypertension

\begin{tabular}{|c|c|c|c|c|c|c|c|}
\hline & \multicolumn{2}{|c|}{$\begin{array}{l}\text { Normal } \\
(\mathrm{N}=140)\end{array}$} & \multicolumn{2}{|c|}{$\begin{array}{c}\text { Hypertension } \\
(\mathrm{N}=70)\end{array}$} & \multirow{2}{*}{$\begin{array}{l}\text { Crude } \\
\text { odds } \\
\text { ratio }\end{array}$} & \multirow{2}{*}{$\begin{array}{c}95 \% \\
\text { Confidence } \\
\text { interval }\end{array}$} & \multirow[t]{2}{*}{$\mathrm{p}$} \\
\hline & $\mathrm{n}$ & $\%$ & $\mathrm{n}$ & $\%$ & & & \\
\hline \multicolumn{8}{|l|}{ Marital status } \\
\hline Married & 134 & 95.7 & 67 & 95.7 & 1.00 & Reference & \\
\hline Divorced/widow(er) & 5 & 3.6 & 3 & 4.3 & 1.20 & $0.28-5.17$ & 0.807 \\
\hline Unmarried & 1 & 0.7 & 0 & 0 & $\mathrm{~N} / \mathrm{a}$ & & \\
\hline \multicolumn{8}{|l|}{ Education } \\
\hline Junior high school & 16 & 11.4 & 3 & 4.3 & 1.00 & Reference & \\
\hline Senior high school & 25 & 17.9 & 13 & 18.6 & 2.77 & $0.68-11.28$ & 0.154 \\
\hline Academy & 35 & 25.0 & 20 & 28.6 & 3.05 & $0.79-11.75$ & 0.106 \\
\hline Graduate & 64 & 45.7 & 34 & 48.6 & 2.83 & $0.77-10.41$ & 0.117 \\
\hline \multicolumn{8}{|l|}{ Level of employment } \\
\hline Low & 12 & 8.6 & 2 & 2.9 & 1.00 & Reference & \\
\hline Middle & 65 & 46.4 & 25 & 35.7 & 2.30 & $0.48-11.05$ & 0.295 \\
\hline High & 63 & 45.0 & 43 & 61.4 & 4.09 & $0.87-11.05$ & 0.074 \\
\hline \multicolumn{8}{|l|}{ Type of employment } \\
\hline Staff & 116 & 82.9 & 42 & 60.0 & 1.00 & Reference & \\
\hline Supervisor & 9 & 6.4 & 14 & 20.0 & 4.30 & $1.73-10.66$ & 0.002 \\
\hline Advisor & 3 & 2.1 & 8 & 11.4 & 7.36 & $1.86-29.07$ & 0.004 \\
\hline Others & 12 & 8.6 & 6 & 8.6 & 1.38 & $0.49-3.91$ & 0.544 \\
\hline \multicolumn{8}{|l|}{ Length of employment } \\
\hline 2-10 years & 12 & 8.6 & 1 & 1.4 & 1.00 & Reference & \\
\hline 11-20 years & 70 & 50.0 & 10 & 14.3 & 1.71 & $0.20-14.64$ & 0.622 \\
\hline 21-30 years & 48 & 34.3 & 25 & 35.7 & 6.25 & $0.77-50.86$ & 0.087 \\
\hline 31-37 years & 10 & 7.1 & 34 & 48.6 & 40.8 & $4.71-353.21$ & 0.001 \\
\hline \multicolumn{8}{|l|}{ Additional work } \\
\hline None & 98 & 70.0 & 53 & 75.7 & 1.00 & Reference & \\
\hline Yes & 42 & 30.0 & 17 & 24.3 & 0.75 & $0.39-1.44$ & 0.386 \\
\hline
\end{tabular}

N/a $=$ Not applicable

Table 2. Activity, habit, work-related stressors and risk of hypertension

\begin{tabular}{|c|c|c|c|c|c|c|c|}
\hline & \multicolumn{2}{|c|}{$\begin{array}{l}\text { Normal } \\
(\mathrm{N}=140)\end{array}$} & \multicolumn{2}{|c|}{$\begin{array}{l}\text { Hypertension } \\
(\mathrm{N}=70)\end{array}$} & \multirow{2}{*}{$\begin{array}{r}\text { Crude } \\
\text { odds } \\
\text { ratio } \\
\end{array}$} & \multirow{2}{*}{$\begin{array}{c}95 \% \\
\text { Confidence } \\
\text { interval }\end{array}$} & \multirow[t]{2}{*}{$\mathrm{P}$} \\
\hline & $\mathrm{n}$ & $\%$ & $\mathrm{n}$ & $\%$ & & & \\
\hline \multicolumn{8}{|l|}{ Daily drinking coffee } \\
\hline No & 47 & 33.6 & 14 & 20.0 & 1.00 & Reference & \\
\hline Less than four cups & 87 & 62.1 & 51 & 72.9 & 1.97 & $0.99-3.92$ & 0.054 \\
\hline Four cups or more & 6 & 4.3 & 5 & 7.1 & 2.80 & $0.74-10.56$ & 0.129 \\
\hline \multicolumn{8}{|l|}{ Role ambiguity score } \\
\hline Low & 83 & 59.3 & 23 & 32.9 & 1.00 & Reference & \\
\hline Moderate/High & 57 & 40.7 & 47 & 67.1 & 2.97 & $1.63-5.43$ & 0.000 \\
\hline \multicolumn{8}{|l|}{ Role conflict score } \\
\hline Low & 61 & 43.6 & 12 & 17.1 & 1.00 & Reference & \\
\hline Moderate & 79 & 56.4 & 58 & 82.9 & 3.73 & $1.84-7.56$ & 0.000 \\
\hline \multicolumn{8}{|c|}{ Personal responsibility score } \\
\hline Low & 48 & 34.3 & 9 & 12.9 & 1.00 & Reference & \\
\hline Moderate/High & 92 & 65.7 & 61 & 87.1 & 3.54 & $1.62-7.73$ & 0.002 \\
\hline
\end{tabular}


Table 3. Relationship between, body mass index, habits, family history of hypertension, work-related stress and risk of hypertension

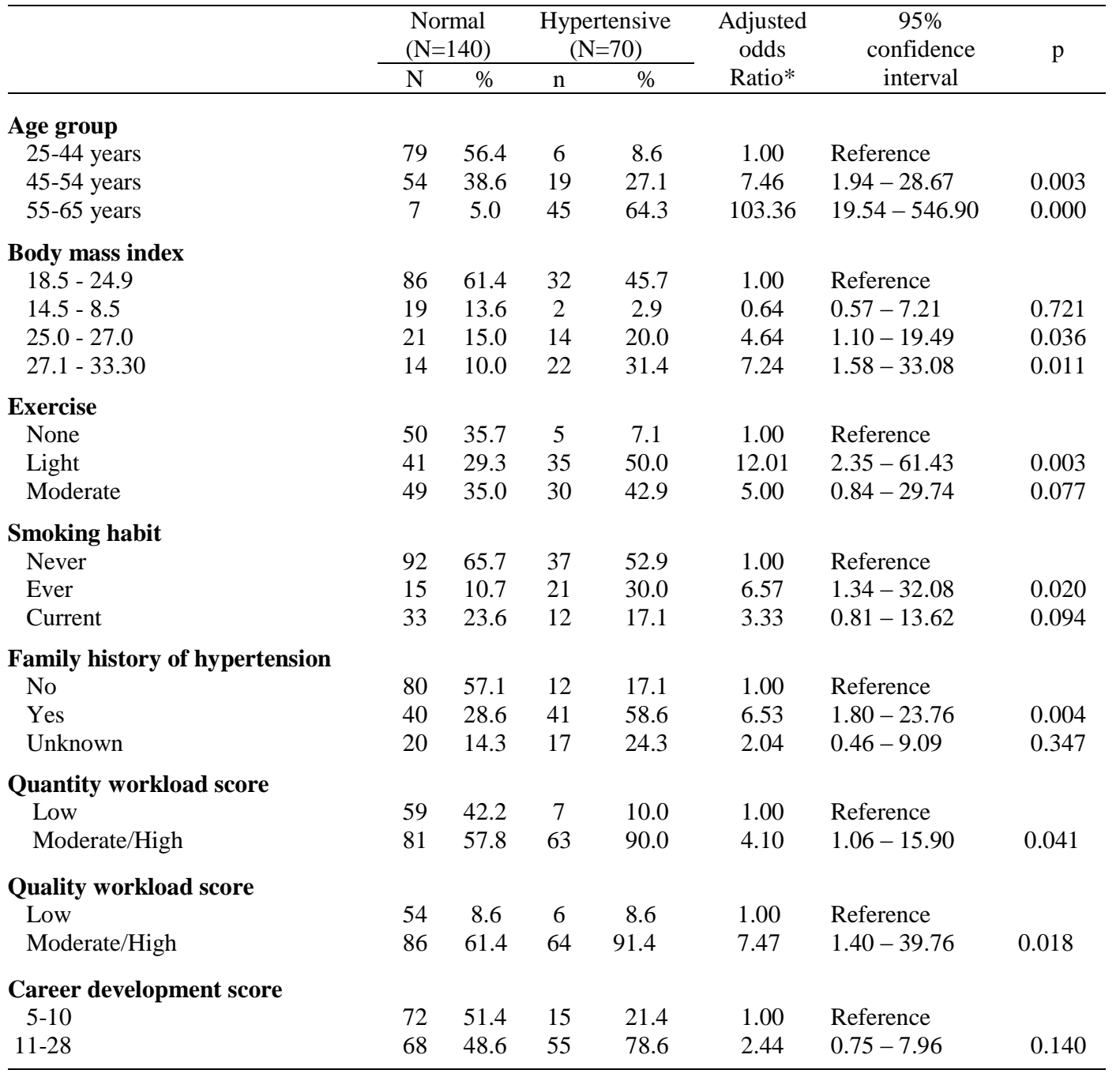

* Adjusted each others for listed risk factors listed on this Table

\section{DISCUSSION}

This study has some limitations. Firstly, it cannot show cause and effect between risk factors and hypertension. There were also biases in population, subject selection, sample size and information or data obtained.

The subjects came from a limited population, which were employees aged $25-65$ years. The results therefore are only suitable for the designated population or other populations having the same characteristics.

The psychometric instrument used for stress diagnostic survey was self-rated which depend on the honesty and responsibility of the respondent in answering the questionnaires. To overcome this bias, a standard form was used and the questionnaires were completed through an interview by the author. If the subject was in doubt, the interviewer will attempt to guide for a more accurate answer.

Another source of information bias was the other risk factors that were not evaluated, among others, were household activities, diabetes mellitus, cholesterol level, personality types, and environment. Noise was not measured in this study. Several studies have shown the effect on noise on hypertension and on work-related stress. ${ }^{13}$ 
Other than work, stressors relating to hypertension such as stressors at home (marriage life, finance, living surroundings etc), stressors in social life (social interaction, hobbies, social activities etc) and stressors on the way to work (traffic jams, means of transportation, the length of time getting to work etc). ${ }^{14}$

Examination for stress and personality were not included because of the length of the interview. The time allocated for the interviews were limited to 30 minutes during working hours, and no rest period could be used for the interviews. The employees were scheduled to come one at a time to the outpatient clinic to be examined and interviewed. On a few instances, when the employees were very busy and could not come to the clinic, the first author had to come to their office (desks) to do the examination and interview.

Diabetes mellitus and cholesterol level were not included in this study because some of the medical records were incomplete.

There was also some limitation to the secondary data obtained, since the author was only given access to the most recent medical check-up results of December 2003 - January 2004. Reconfirmation of interviews and questionnaires can only be made from the medical records of employees visiting the clinic for some other medical reason.

Out of 231 subjects examined, there were $30.3 \%$ cases of hypertension. This was similar to the results of the MONICA II project in South Jakarta (2000) where the prevalence of stage 1 and stage 2 hypertension was $31.5 \%$ among subjects consisted of $93.9 \%$ employees and $6.1 \%$ unemployed (personal communication with the MONICA II project team).

The number of new cases of hypertension fluctuated each years, the highest was in 2001, followed by 2003. The cause of this fluctuation could be the impact of the economic crisis which was felt from 2000. Many business concerns declined and had to reorganize in order to become more efficient in all aspects. One alternative was to downsize the ever growing work force. This could be a source of workrelated stress for the workers, leading to anxieties from loss of work and finally developing new cases of hypertension.

Most subjects with hypertension (77.1\%) were still on antihypertensive medication. This was probably due to the adequate health facilities with excellent service making the patients willing to control their blood pressure on a regular basis. The health promotion and counseling programs for patients with hypertension also added the success. On the other hand, the community MONICA project found only $11.5 \%$ hypertensive patients were still taking antihypertensive medication (personal communication).

When compared to the 25 - 44 age group, those in the $45-54$ age group had a 7 -fold risk of hypertension, while those in the $55-65$ age group had a 100 -fold risk of hypertension. The large increase of hypertension in the $55-65$ age group, with a small number of subjects with normal blood pressure, caused the risk of developing hypertension to be high with a very wide confidence interval. Our finding was in accordance with previous studies that increasing age will increase the risk of hypertension. ${ }^{1,3,4,14,15}$

The MONICA II project (2000) in Jakarta has also shown the increase of prevalence in hypertension in the older subjects. Prevalence was highest in the $55-$ 64 age group, which was $10.9 \%$ from a total prevalence of $31.5 \%$. The results of our study was also consistent with a study in Bogor rural area (2000) where those aged 40 or more years were at a higher risk of having hypertension compared with those aged $18-39$ years, with a significant 21 -fold rise of hypertension in the $55-59$ age group. ${ }^{15}$

It was found that the greater the body weight of the subject the higher the risk of hypertension. This findings was consistent with findings of a study in a Bogor rural area $(2000)^{15}$ and other studies in Bangladesh and India, and in Semarang. ${ }^{16,17}$

Univariate analysis of the six work-related stressors showed that these factors were correlated with the risk of hypertension, but the factors that included in the final model were qualitative and quantitative increase in workload. Qualitative increase in workload increased the risk of hypertension 7-fold, compared to the 4-fold increased risk of hypertension caused by quantitative increase in workload.

Compared to those that did not smoke, smoking was linked with a 6.3-fold increase in the risk of hypertension, and among those that were still smoking the risk was 5-fold. This findings fit "the healthy workers survivor effect", 19 the phenomenon that explains a person in excellent physical, mental, and general health will be stronger and can survive. The 
subject that still smokes but was in excellent physical, mental and overall health will have a smaller risk of developing hypertension.

A family history of hypertension is correlated with a risk of developing hypertension. This is consistent with a theory put forth by Kaplan, which states that a person with hypertensive parents had a 2-fold risk of hypertension. ${ }^{14}$

Qualitative increase in workload was found to be stronger in increasing the risk of hypertension. This was probably due to advances in technology and the use of modern machinery, replacing simple manual work with work requiring more brain than brawn. Work becomes more complex and need more technical and intellectual know-how than the average workers possess, this can be a stressor that may lead to hypertension. ${ }^{20}$

Quantitative increase in workload can also increase the risk of hypertension. Friedman has stated that quantitative increases in workload is associated with time, and the chronic pressures of time will have a damaging effect on the cardiovascular system, manifested by premature heart attacks and/or hypertension. ${ }^{20}$

Career development moderately influences the risk of hypertension. The reason could be because of business reorganization due to the economic crisis. Reorganization means uncertainty, making the employees afraid of losing their jobs. Career development can also be the result of increased or decreased promotions. A 1990 study in Japan found that job promotions, which is a component of career development, can influence the risk of developing hypertension. ${ }^{21}$ The study found that employees that were not promoted had a $11.2 \%$ increased risk of hypertension in 5 years, while those that were promoted had a $5.2 \%$ risk of hypertension. ${ }^{21}$

Univariate analysis showed that education was moderately correlated $(\mathrm{p}<0.25)$ to the risk of hypertension, which may be due to the high education level of the majority of the employees. One of the factors influencing work-related stress is education. The high level of education along with changing global conditions increases the competition in the job market, causing stress that may lead to hypertension. But in the final model, education did not seem to affect the risk of hypertension, probably other more significant factors masked the effect of education.
Role ambiguity, role conflict, and personal responsibility were excluded from the final model. This was probably due to other dominant factors, such as age, body mass index, physical activity, smoking, and family history of hypertension.

The level of employment was not found to be correlated to the risk of hypertension. This finding was consistent with prior findings on high echelon male government officials in Jakarta $2000 .^{21}$ The reason could be the different stressors occurring in the different levels of employment or the successful use stress management on a personal basis. Another reason could be the sample size not sufficient to correlate the level of employment to the risk of hypertension.

Although univariate analysis showed that drinking coffee, the type of employment and length of employment were more likely to increase the risk of hypertension, these factors were not included in the final model. The type of employment was probably masked by other factors, such as age, the quantitative increase of workload, the qualitative increase of workload, and career development. A lengthy period of monotonous employment compounded with boredom can cause psychological stress leading to increased blood pressure. ${ }^{8}$

The effects of coffee drinking on increasing blood pressure are still debatable. This study found that the habit of drinking coffee was not correlated to hypertension. This finding was consistent with Myers' opinion that drinking moderate amounts of coffee regularly will not affect blood pressure, because the body builds tolerance towards coffee. But other authors state that the caffeine in the coffee will increase blood pressure. ${ }^{14}$

In conclusion, this study revealed that seven risk factors related to hypertension, namely age, body mass index, exercise and smoking habits, family history of hypertension, quantity as well quality working load scores, and career development score. Increasing age and higher BMI will increase the risk of hypertension. Moderate exercise will lower the risk of hypertension. Furthermore, those with a family history of hypertension, higher quality and quantity working load scores and career development scores had an increased risk of hypertension. In order to minimize the risk of hypertension, these stressors should therefore be prevented. 


\section{Aknowledgment}

The authors thank all the subjects who cooperatively participated in this study. We also express special gratitude to Dr. Guntur Tjora and Dr. Minarma Siagian for their assistance.

\section{REFERENCES}

1. Basuki B, Soemarko DS, Amri Z, Ibrahim EI. Past antihypertensive drugs, obesity, daily light working load and risk of hypertension: An Indonesian rural study. Med J Indones 2001;4:224-9.

2. Sigarlaki HJO. Stres, merokok, dan jenis kelamin tidak berisiko pada penderita hipertensi di RSU FK-UKI Jakarta. Maj Ked FK UKI 1999;39:32-40.

3. Raflizar. Masalah hipertensi dan penanggulangannya. MKI 2003; 50;1:55-60.

4. National Heart, Lung and Blood Pressure Institute. The seventh report of the joint national committee on prevention, detection, evaluation, and treatment of high blood pressure. National Institutes of Health; 2003.

5. Iswanto Yun. Analisis hubungan antara stres kerja, kepribadian, dan kinerja manajer bank. Jurnal Studi Indonesia 2001;11:21-30.

6. Pickering TG, Devereux R.B, James G.D, Gerin W, Landsbergis P, Schnall PL, Schwartz JE. Environmental influences on blood pressure and the role of job strain. $\mathbf{J}$ Hypertension 1996; 14 (suppl 5):179-85.

7. Basuki B. Aplikasi metode kasus-kontrol. Jakarta: Ilmu Kedokteran Komunitas Fakultas Kedokteran Universitas Indonesia; 2002.

8. National Heart, Lung and Blood Pressure Institute. The seventh report of the joint national committee on prevention, detection, evaluation, and treatment of high blood pressure. National Institutes of Health; 2003.

9. Ministry of Health RI. Action on stress at work. Jakarta: The Ministry; 2000.

10. StataCorp. Stata statistical software: Release 6.0. Texas: College Station; 2000.

11. Hosmer DW, Lemeshow S. Applied logistic regression. $2^{\text {nd }}$ ed. New York: John Willey \& Sons; 2000.

12. Breslow NE, Day NE. Statistical methods in cancer research. Vol I. The analysis of case-control studies. IARC Sci Publ No.32. Lyon: International Agency for Research on Cancer; 1980.

13. Jarup L, Dudley M-L, Babish W, Houthuijs D, Swart W, Pershagen G. Hypertension and exposure to noise near airport (Hyena): Study design and noise exposure assessment. Environ Health Perspect 2005;113:1473-8.

14. Kaplan NM. Clinical hypertension $8^{\text {th }}$ ed. Philadelphia : Williams \& Willkins. 2002.

15. Basuki B, Setianto B. Age, body posture, daily working load, past antihypertensive drugs and risk of hypertension: A rural Indonesian study. Med J Indones 2001;10: 29-33.

16. Hypertension Study Group. Prevalence, awareness, treatment and control of hypertension among the elderly in Bangladesh and India: A multicentre study. Bulletin of the WHO 2001:79:490-500.

17. Rahmatullah P. Gambaran tekanan darah pada kasuskasus obesitas. J. Kardiol Indones 1999;24:147-53.

18. Joesoef AH. Latihan fisik dan hipertensi. J Kardiol Indones 1994:17:81-4.

19. Arrighi HM, Hertz-Piciotto I. The evolving concepts of the healthy worker survivor effect. Epidemiol 1994;5:186-96.

20. Munandar AS. Stress dan keselamatan kerja, psikologi industri dan organisasi. Jakarta: UI Press; 2001.

21. Kubo YC, Iamoto TM, Uwozono JS, Obayashi EK, Ogawa KN. The effect of job related factors and life styles on the five cumulative incidence of hypetension in Japanese steel works. J Occupat Health 2000;42:304-14. 